
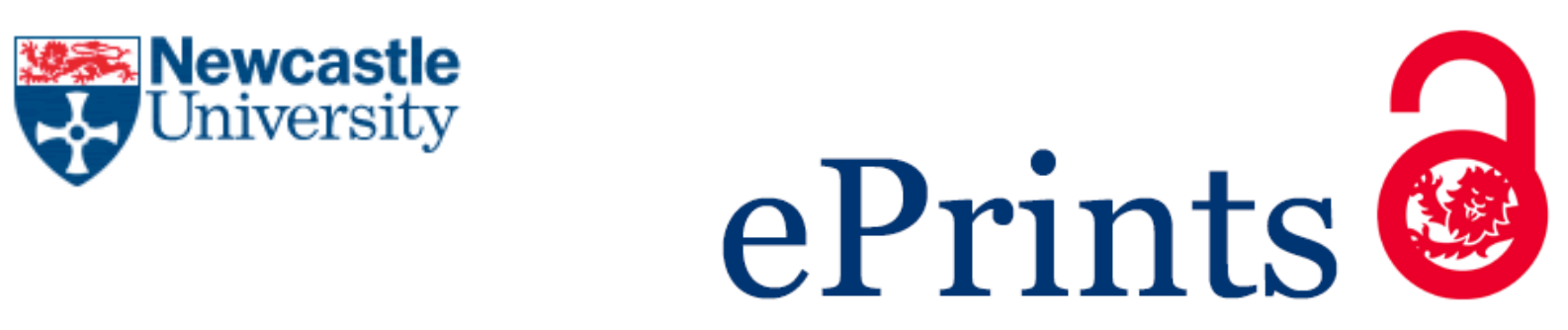

Behr H.

Conditions of critique and the non-irreversibility of politics.

Journal of International Political Theory (2016)

DOI: http://dx.doi.org/10.1177/1755088216671734

\title{
Copyright:
}

This is the author's accepted manuscript of an article that has been published in its final definitive form by Sage Publications Ltd, 2016.

DOI link to article:

http://dx.doi.org/10.1177/1755088216671734

Date deposited:

$02 / 03 / 2016$

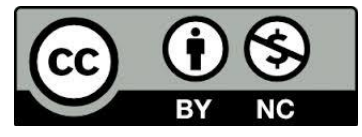

This work is licensed under a Creative Commons Attribution-NonCommercial 3.0 Unported License 


\section{Conditions of critique and the non-irreversibility of politics}

\section{Hartmut Behr}

Newcastle University, UK

\section{Abstract}

Critique is a driving force not only for the development of political ideas and concepts, but also for protecting humane and democratic politics against the perils of epistemic and political ideologies. Yet, while there is much debate about the question of 'What is critique?', the conditions of critique appear largely under-reflected in International Politics and the Social Sciences more generally. This paper goes beyond the question of what critique in politics and social science might consist of and holds that critique is not an end in itself, but rather requires a yardstick to discuss and judge its generative conditions, i.e., its foundation, legitimization, and direction that it must pertain to be meaningful. The following paper will explore the oeuvres of $20^{\text {th }}$-century political and social theorists Hans J. Morgenthau, Herbert Marcuse, and Eric Voegelin and argues that the three principles of perspectivity', negation', and 'noesis' that can be concluded from their work provide such generative conditions of critique, practically leading to a novel policy framework of the nonirreversibility of politics.

\section{Keywords}

Conditions of critique, perspectivity, negation, apperception, non-irreversibility of politics

\section{Introduction}

Critique seems to assume that we are in a better or superior position than the author, text, or politician that is criticized; but what justifies this assumption? In researching this question, this paper attempts to go beyond the question of 'What is critique?', ' but asks what enables and legitimizes the social scientist, the philosopher, the politician, finally every one of us, to be critical. While Herbert Marcuse's, Hans J Morgenthau's, and Eric Voegelin's work is each deficient in explicating their conditions of critique, together and combined they promise to hold important insights to elaborate conditions of critique and of humane politics.

Even though the work of Morgenthau, Marcuse, and Voegelin does not explicitly reflect upon the conditions of (their) critique, their oeuvres nevertheless hold crucial insights for the formulation

\section{Corresponding author:}

Hartmut Behr, School of Geography, Politics, and Sociology, Newcastle University, Newcastle upon Tyne, UK, NE1 7RU

Email: Hartmut.behr@ncl.ac.uk 
of knowledge and its practical application. These insights become visible as conditions of critique when elaborated through intertextual analysis. An intertextual triangulation of their views on knowledge production and political/social practice, that takes into account their different approaches and lessons while at the same time interrelating them, thus promises significant findings about the under-researched question of what enables, legitimates, and directs critique.

While Marcuse argues that in modern (advanced industrial) societies the individual would be bereft of his/her ability to critique because technological developments would work against human liberation and the human condition as means of control and command, he himself then presents a whole book (and more) of and on social and political critique. ${ }^{2}$ But what are the conditions of his critique and the possibilities he offers? His notion of dialectic negation seems fundamental and stimulating for the study of conditions of critique.

His contemporary Morgenthau was certainly not shy of critiquing politicians and colleagues, in publications, speeches, and political action. Indeed, he was very much an alerting voice and public intellectual against, academically, positivist science, a-historical inquiry, and dehumanizing tendencies of a priori-rationalizations in the social sciences; and, politically, of modern ideologies of social planning, consumer society, and national power politics. ${ }^{3}$ We find in Morgenthau's writings, however, even less reflection on the conditions that enabled his critique than in Marcuse. However, when taking into account, too, his unpublished work, we can elaborate the notion of the contingency of political knowledge and practice as, too, the conditions of his own arguments.

And Voegelin, probably the least known to students of International Politics, is often associated with conservative scholarship, shares, however, many critiques with Critical Theory and Classical Realism as of modern reason, of the idea of an autonomous individual, and of nationalism and political ideologies (even if all three arrived at different answers) ${ }^{4}$. But it also needs to be asked here: what enables his critique? And what thoughts can we find in his work with regard to the question of conditions of critique? His specific contribution - which comes to full fruition under the present inquiry when linked and combined with the notions of perspectivity (à la Morgenthau) and 
dialectic negation of knowledge (à la Marcuse) - lies in the embedding of 'negative', deconstructing knowledge by means of perspectivity and negation into a 'positive' re-articulation of humanity and political order through the notion of 'noesis'.

More specifically, Morgenthau's idea of the temporal and spatial contingency and perspectivity of knowledge (a concept that he develops in reference to Karl Mannheim's concept of "Standortgebundenheit"), combined with the notion of a dialectical negation of arguments as discussed by Marcuse (as 'thesis' and 'anti-thesis'), need to be framed and embedded within the concept of 'noesis' (i.e., apperceiving self-reflectivity) as interpreted by Voegelin. The triangulation of perspectivity and dialectical negation with political 'noesis' provides a catalogue of principles that prevent epistemic and political ideologies and safeguard humane and pluralistic politics. ${ }^{5}$ This triad translates into four practical propositions for research and politics that found a new normative approach to a politics of non-irreversibility alluded to in the Conclusions.

\section{The argument}

This paper develops the following argument: while there are two epistemological requirements that enable critique - the idea of the conditionality and space-time-contingency of political knowledge and the idea of negation - there seems to be the necessity to complement both with the notion of 'noesis', i.e., the apperceiving reflectivity of critique on its own structures, reason, and experience. While "Standortgebundenheit" and negation rest on temporal ontology, suggesting the "transformativity', rather than identity of social relations and political order, ${ }^{6}$ we need to ask the subsequent question of what kind of referent 'object' "Standortgebundenheit" and negation relate to and need to resonate with. If knowledge is perspectivist, negated, and temporal, i.e., of deconstructing quality, what then is the epistemological yardstick for rearticulating, creating, and practicing political order? 
Voegelin's notion of 'noesis' provides us with a fruitful answer, drafting theoretical and political-strategic openness towards and apperceiving reflection upon perspectivism and negation as the condition of humanity and humane politics to prevent epistemic and political ideologies. It thus triangulates perspectivism and negation and incorporates them into a catalogue of conditions of critique. Keeping open, and if necessary creating and recovering unoccupied (by predisposed political ideas, practices, structures, and institutions), deliberative spaces protects humane politics. In sum, the triangulation of 'noesis', dialectic negation, and "Standortgebundenheit" are much more than normative thinking about politics: they not only provide theoretical principles, but offer indispensable tools for the critique of political claims and practices when and as soon as they violate and harm humane and democratic (i.e., as will be argued in the Conclusions, reversible) politics. Thus, they deliver necessary critical standards of humanity vis-à-vis political theory and political practices, finally, too, for our own arguments and practices.

\section{Structure of the Paper}

These expositions result in the following structure of paper: in a first step, I will discuss the idea of the conditionality and space-time-contingency of knowledge and political theory in Morgenthau. In a second step, I will then elaborate on the idea of dialectical negation in Marcuse. In a third step, I will elaborate Voegelin's notion of 'noesis'. In a fourth section, I will bring these discussions together in the light of the main question of conditions of critique and conclude the following four practical consequences for research and politics:

(1) Research concepts and practices need to be framed in relation to the historical and cultural circumstances of the researcher and the "object"-under-study, while there is no independent, 'objective' vantage point for the development and application of concepts and research strategies. 
(2) Every research process and research finding needs to incorporate the possibility of alternative views and suggest its own refutability. Accordingly, it has to imply in such cases a discreet and diplomatic option for the normative and political practice that might result from itself.

(3) Research in international politics and the social sciences more generally has to resonate with human experience, the apperception of humanity, and 'the person', ${ }^{7}$ rather than with policies of progress, performance measurement, social engineering, and institutional design as if these were ends in themselves.

(4) With regard to practical politics, the claim arises of the non-irreversibility of political practice, i.e., politics shall not result in consequences that are irreparable and unalterable. This aspect will be elaborated as an instrument to assess and evaluate concrete policies, connecting to, and the same time providing innovative ground for, contemporary theoretical and policy debates such as on energy, environmental, and security issues. ${ }^{8}$

\section{On the perspectivity of knowledge and political theory}

There are several threads throughout his oeuvre where Morgenthau points out that all theory and theoretical analysis are contingent upon factors the occurrences of which we had no knowledge of and consequences which we could not foresee. Even if prominently communicated in The Concept of the Political (2012 [1933]), it was not before a talk at the University of Maryland in 1961, with the title 'The Intellectual and Political Functions of a Theory of International Relations' (here 1962b), that Morgenthau used the precise term 'standortgebunden' to describe the spatial and temporal conditionality of political and social theory and knowledge. The adjective 'standortgebunden', and the noun 'Standortgebundenheit', are from sociologist Karl Mannheim and is a key concept of Mannheim's sociology of knowledge $(1936 ; 1984)$. It describes the idea that social theory always depends upon the social and political environment in which it has been formulated and in which it is supposed to operate. This term endorses a perspectivist understanding of an object re- 
vealing characteristics of itself only in relation to concepts and perspectives applied. Accordingly, all social and political knowledge is historical and spatial. In addition to his statements from The Concept of the Political and in 'The Intellectual and Political Functions' we find in the Third of Morgenthau's 'Six Principles of Political Realism' ${ }^{\text {'9 }}$ no less than three paragraphs which most explicitly explain this position in relation to the concepts of power and interest:

(The) kind of interest determining political action (...) depends upon the political and cultural context within which foreign policy is formulated. The goals (...) pursued by nations (...) run the whole gamut of objectives any nation has ever pursued or might possibly pursue.

The same observations apply to the concept of power. Its content and the manner of its use are determined by the political and cultural environment (...) Power covers all social relationships (...).

What is true of the general character of international relations is also true of the nation state as the ultimate point of reference of contemporary foreign policy (...) (The) contemporary connection between interest and the nation state is a product of history, and is therefore bound to disappear in the course of history.

Morgenthau's epistemological position of 'Standortgebundenheit' coincides with his criticism of the rationalist and positivist ideas of historical progress, techniques of social engineering, and the rationality of the 'Age of Reason' which all require a universal standpoint of knowledge from which to derive these ideas and respective strategies for their realization. Further to his published oeuvre - such as Scientific Man vs. Power Politics (1946), 'The State of Political Science' (here 1962a) or his The Concept of the Political (see also above in footnote 2) -, we have additional evidence from his 1952-lecture 'Philosophy of International Relations', particularly that of $31^{\text {st }}$ January, as well as most strikingly from letters between Morgenthau and Karl Gottfried Kindermann from the 1960s. ${ }^{10}$

We thus recognize his critical disassociation from three prominent theories of knowledge: First, he is critical about a rationalist approach to overcome the confinements of human knowledge through the construction of knowledge of the external world out of indubitable principles possessed 
inherently by the mind itself, the most indubitable of such principles being Descartes's 'Cogito ergo sum'. This kind of rationalist knowledge would be invulnerable to any kind of scepticism and is supposed to represent the basis of all further knowledge about the world. ${ }^{11}$ We recognize here the belief that the existence of objects outside the self can be based on and deduced from the mind's awareness of its own existence, thereby allowing to dispel all doubts and insecurities about knowledge and accomplishing epistemological security regarding the existence, constitution, and character of the world (also called 'dualism'; see Holt et al., 1960: 154). Morgenthau promotes a position that is critical about this epistemological paradigm, especially with regard to its a priori, experience-independent claims and assumptions about the world (see Behr, 2013). Political realism in Morgenthau is hence an anti-Cartesian position which recognizes the mind-independent existence of an empirical world and human agency within this world, but which does not, however, claim secure and definite knowability of, and analytical accessibility to, this world. His realism is aware that there exist factualities about the world and its penetrating principles that are mind-independent, but that those 'facts' and principles, however, adopt different empirical meanings throughout history and cultures; they are conditioned and shaped by time and space-contingent constellations created through human mind, perception, imagination, and agency. ${ }^{12}$ This epistemological position recognizes perennial forces which penetrate political reality, but requires for their understanding contextspecific explanations and hermeneutic methods; in short, it is "Erfahrungswissenschaft" that proclaims universal epistemological positions while at the same time demanding temporally and spatially sensitive explanations of particular manifestations of those perennial forces.

Second, Morgenthau is also adverse to an empiricism which would base knowledge about the political world on merely sensually conceived impressions and which would rely in its assertions about the world on (ostensibly) mind-independent data bruta, i.e. methodologically on positivist quantifications and measurements of social and political phenomena, built on the hope that through inductive logic there may be some day some kind of spill-over from data collection to knowledge (see also the discussions in Holt et al. 1960: 152). 
And third, Morgenthau's epistemology, because it recognizes the mind-independent, however spatio-temporally qualified status of things real, 'strips mind of its pretensions, but not of its value or greatness (...) Realism dethrones the mind, [and at the same time] recognizes mind as chief in the world' (Alexander 1960: 186). We here further recognize an anti-idealist position against the belief in a 'world in which there exist only minds' (Holt et al. 1960: 154, 155). Politically speaking, and in sharp contrast to Morgenthau's position, idealism would presume the fabricability and shapability of the world without, as he argues, taking into account to a sufficiently high degree the concepts of power, interest, and morality and the 'factual', but empirically divergent constellations, which these concepts make cognizable. He notes:

For realism, theory consists in ascertaining facts and giving them meaning through reason. It assumes that the character of a foreign policy can be ascertained only through the examination of the political acts performed and of the foreseeable consequences of these acts (...) Yet examination of the facts is not enough. To give meaning to the factual raw material of foreign policy [here, we recognize Friedrich Nietzsche's "facts are stupid"13], we must approach political reality with a kind of rationale outline, a map that suggests to us (...) possible meanings of foreign policy (from the First of his 'Six Principles ...').

This 'map' ${ }^{14}$ for the rational (and very purposefully Morgenthau does not write rationalist) conceptualization of reality is provided by the concepts of power, interest, and morality and their interplay. These concepts, which condensate in his mantra 'interest defined in terms of power' (from the Second of his 'Six Principles ...'), are such a rational conceptualization. They do not express an ontological statement of how the world 'is', even if they became read, or better misread as such by International Relations mainstream time and again. In Morgenthau's words they can rather be understood as a 'signpost that helps political realism to find its way through the landscape of international politics' (ibid.). Here it becomes clear that this sentence articulates epistemological categories which 'provide the link between reason trying to understand international politics and the facts to be understood' (ibid). And this is precisely not a subordination of political reality under either rationalist, empiricist, or idealist principles Another quote in this context is further instructive for the epis- 
temological character of the concepts of power and interest: 'The concept of interest defined as power imposes intellectual discipline upon the observer' (emphasis by the authors; from the Second of his 'Six Principles ...'). ${ }^{15}$

In order to further understand epistemology in Morgenthau - and 'realism' is to be understood as epistemology, ${ }^{16}$ not as an ontology of international politics as often misread - we need to emphasize his statements that empiricist and positivist accounts would indeed 'become a pretentious collection of trivialities' (1962a: 27). He insists that empirics has to be given social and political meaning (from his First of his 'Six Principles ...') and that, as he notes elsewhere and much earlier (in 1951; here 1962a), 'the empiricist commitment of modern political science to practical ends [i.e. as a 'problem-solving' empiricist science] (...) has powerfully contributed to its decline as theory' (25). This criticism resonates with his argumentation against analogies between natural and social sciences and humanities, arguing that '(to) make susceptibility to quantitative measurement the yardstick of the scientific character of the social sciences (...) is to deprive these sciences of that very orientation which is adequate to the understanding of their subject matter' (1962a: 27). It is obvious that these arguments vehemently targeted the increasing scientism of American political science in the 1940s and 1950s, and thus were against the emerging mainstream in the discipline of which the subdiscipline of International Relations was by no way exempted. ${ }^{17}$ But what would be epistemologically adequate? We can understand Morgenthau's epistemology as a middle-ground between empiricism and rationalism; he notes:

While it is unnecessary to argue the case for the need for factual information, it ought to be no more necessary to argue that factual description is not science, but a mere (...) preparation for the scientific understanding of the facts (1962a: 26).

Therefore, realist epistemology consists in the acknowledgment of the existence of mindindependent political realities in which, however, the mind plays a paramount role in that these mind-independent realities become meaningful only through theoretical understanding. Further to this, these 'facts' are not to be seen as eternally the same, but have to be recognized in their spatio- 
temporal constellations. This fundamental position of realist epistemology posits that both the thing-being-observed and the observer mutually influence and constitute each other in (the world of) social sciences. ${ }^{18}$ This mutual constitution of observer and the thing-being-observed was selfevident for Morgenthau who was familiarized with this epistemological position through readings of Friedrich Nietzsche, Wilhelm Dilthey, Georg Simmel, Alfred Schütz, and Karl Mannheim. ${ }^{19}$

\section{Dialectic negation}

The second principle of critique that shall be introduced is the idea of dialectic negation as we know it from critical theory. I will draw mainly on Herbert Marcuse's work since this principle communicates most clearly from his writings, particularly from his Negations: Essays in Critical Theory (1968). At first, however, we have to emphasize the anti-metaphysical argument of critical theory that is, according to its self-understanding, one of the main differences between 'traditional' and 'critical' theory. ${ }^{20}$ This anti-metaphysical position is understood and targeted against the metaphysical speculation about an essence and telos of things (history, society, man, etc.). Against such speculation, critical theorists stress the importance of history, i.e., historical experience and historical inquiry. In the Introduction to his One-dimensional Man, when addressing the question of what critical theory is, Marcuse famously describes critical theory as the attempt to elaborate historical alternatives to actual pathways of societal developments; ${ }^{21}$ and in Negations, he writes:

Through [critical theory], given facts are understood as appearances whose essence can be comprehended only in the context of particular historical tendencies aiming at a different form of reality. The theory's historical interest enter constitutively into its conceptual scheme and makes the transcendence of 'facts' towards their essence critical and polemic' (1968: 71).

This takes us to the core of critical theory and its notion of dialectic negation. To find out those historical alternatives and possibilities of its realization, including reasons for why other pathways of historical development have dominated, is linked to the ideas of emancipation and liberation. The 
awareness and elaboration of historical alternatives and potentialities underlines man's potential role as creator of his social, political, and economic conditions. Here, Marcuse, at least, speaks to us as if he were driven by the idea to rescue some of the Enlightenment promises which have been so pessimistically dismantled by his peers Theodor W. Adorno and Max Horkheimer. ${ }^{22}$

The search for historical alternatives within critical theory and Marcuse is guided by the idea that there actually is and would have been an alternative to every actual event, thus for every event there is a potentiality of being-otherwise. This road to permanent and always possible negation and alternatives takes us to the notion of 'dialectic' that is so paradigmatic for critical theory. ${ }^{23}$ Marcuse writes:

Materialist theory thus transcends the given state of fact and moves towards a different potentiality, proceeding from immediate appearance to the essence that appears in it. But here appearance and essence become members of a real antithesis arising from the particular historical structure of the social process of life. The essence of man and of things appears within that structure; what men and things could genuinely be appears in "bad", "perverted" form. At the same time, however, appears the possibility of negating this perversion and realizing in history that which could be. This antagonistic character of the historical process as it is today turns the opposition of essence and appearance into a dialectical relationship and this relationship into an object of the dialectic. ${ }^{24}$

As we can see here, the idea of dialectic and negation does not only relate to materialistic, historical events, thus to 'historical materialism', but also to the awareness and consciousness of the theoretician. The theoretician not only studies historical 'realities' and 'potentialities', but needs to be aware of, and to build-in his/her analysis, a dialectic of the argument. The relation between 'thesis' and 'anti-thesis' and their permanent forward-drive is of both materialistic and intellectual character. This means for the critical theorist that he/she needs to always be aware of the potential and actual negation of the own argument and should even push and develop the own argument towards its own negation. In 'Traditional and critical theory', Horkheimer briefly reflects upon the role of the critical theorist and it is interesting to see how he sees this role; he writes: 
(The person of the theoretician) exercises an aggressive critique not only against the conscious defenders of the status quo, but against distracting, conformist, or Utopian tendencies within his own household. (1999: 214)

And Marcuse notes in relation to the mutual relation of dialectic as having a historical-material and intellectual character at the same time:

The tension between potentiality and actuality, between what man and things could be and what they are in fact, is one of dynamic focal points of this theory of society. It sees therein not a transcendental structure of Being and an immutable ontological difference, but a historical relationship which can be transformed in this life by real men; the incongruity of potentiality and actuality incites knowledge to become part of the practice of transformation.' (1968: 69)

He goes even further and, close to being a metaphysician himself, ${ }^{25}$ argues that the theoretician is in a position to experience historical potentialities that have never been realized. The question is, how? This envisioning seems only possible through a dialectic forward-development of the own theoretical argument and analysis that negates itself as soon as it is made. An indeed this seems to be the idea when he writes: 'Reality is overcome by being comprehended as the mere possibility of another reality' (1968: 83). Although I do not want to elaborate on inner contradictions of Marcuse's arguments, there is one aspect that nevertheless needs to be mentioned as it appears very important to Marcuse and critical theory more generally. In Negations he writes with regard to the theory-practice relation of critical theory:

What, however, if the development outlined by the theory does not occur? What if the forces that were to bring about the transformation are suppressed and appear to be defeated? Little as the theory's truth is thereby contradicted, it nevertheless appears then in a new light which illuminates new aspects and elements of its object' (1968: 142)

Irrespective of this absurdity, we can record that the notion of dialectic negation provokes the theoretician, finally everyone, to be aware of the permanent negation and counter-possibility of 
one's own argument, historically and theoretically. This notion therefore includes the necessity of permanent self-criticality (as either a concurrent aspect within or procedural aspect subsequent to one's own argument and action). This resembles Jacques Derrida's notion of erasure and translates in the proposition of self-refutability. ${ }^{26}$

\section{The notion of 'noesis'}

The third notion that shall be developed here as a principle of conditions of critique is the notion of 'noesis' as developed by Voegelin. He elaborates this notion going back to the Greek philosopher Plato and his dialogue Sophistes where Plato distinguishes a philosopher's and a statesman's knowledge from mere opinion (doxa), with knowledge as the superior and true from of wisdom compared to arbitrary and opinionated rhetoric. ${ }^{27}$ But what is 'noesis' exactly about and how does it relate to the triangulation of concepts for the elaboration of conditions of critique? To the second part of this question first because it relates to the argument of this paper: 'noesis' shall provide us with the direction that critique shall take after the deconstructive, though utterly important notions of perspectivity/contingency and negation. 'Noesis' is thus supposed to help us articulating a principle for the normative reconstruction of politics after critique. But while 'noesis' provides normative direction, this direction needs again to be qualified by the two intrinsic characteristics of knowledge of perspectivity/contingency and negation. The normative (reconstructive) articulation of politics thus needs a mechanism of critique, consisting of perspectivity and negation that is builtin this normative articulation itself, just as critique needs normative direction to not become redundant or arbitrary as end in itself. ${ }^{28}$ But what does Voegelin mean by 'noesis'?

First, 'noesis' is an intellectual operation that critically reflects upon the degree to which political order, its institutions, and its (primarily linguistic, but generally all kind of) symbolizations correspond to humanity, the latter being imagined by Voegelin as the anthropological constitution of mankind. Thus, 'noesis' is a device of reflection and political judgment. What is to be judged, is 
the question of whether, or not, politics is open towards humanity and human experience. Put differently, 'noesis' is about the critical consciousness and awareness (called 'apperception' by Voegelin and in social psychology) of whether, or not, politics violates or apprehends humanity. But how and as what is humanity imagined?

Voegelin refers to an intellectual figure that appears in many different philosophical movements, such as mainly neo-Catholic and neo-Aristotelian, but also post-modern philosophies and critical theory, but that be summarized in its modern articulations as anti-Enlightenment thinking. This figure is called by Voegelin in Aristotelian language the 'divine ground of existence $^{29}$ and perceives human existence as tension between all kind of questions that are neither tangible, nor answerable; they appear sometimes not even as effable. ${ }^{30}$ Such intangibilities and ineffabilities are not, as they would be perceived from linear, teleological worldviews (such as the three epistemologies of rationalism, empiricism, and idealism criticized above by Morgenthau), a deficiency of a particular dark-age, or numb context, or not yet fully developed consciousness. They are rather indicating the fundamental human condition of intellectual and practical limitation; i.e., there will always be unanswerable questions of human and political life, and subsequently uncontrollable and non-manageable political conditions and consequences. According to Voegelin, this is to be respected (apperceived) and not to be violated by knowledge claims that pretend to have respective answers. To give an example: we cannot know, as Voegelin argues, and we will never know the meaning of history. If we thought we would and pretended to know, we fall victim to ideologies, their one-sided knowledge claims, and their promises of Eden. ${ }^{31}$ 'The refusal to apperceive', Voegelin notes, 'has become [...] the central concept for the understanding of ideological aberrations and deformations' (Voegelin, 2006: 122). ${ }^{32}$ Subsequently, it is crucial for human politics to be aware of the tension of human beings' existence as living and participating in a spectrum of intangibilities and ineffabilities and to not attempt to dissolve this tension by claiming final answers and acting upon them and their assumptions respectively. Voegelin writes: 
These experiences of participation in various areas of reality constitute the horizon of existence in the world. The stress lies on experiences of reality in the plural, being open to all of them and keeping them in balance. This is what I understood as the philosopher's attitude, and this is the attitude I found in the open existence of all great philosophers ... To restore this openness of reality appeared to me to be the principal task of philosophy' (Voegelin, 2006: 98).

The awareness and consciousness of such tension as the fundamental human condition is what Voegelin calls 'apperception'. Thus, apperception results from the experience and awareness of the human condition. Further to this, apperception can recapture humanity through this awareness and its emphasis in case of politics that are not open to the human condition, thus ideological. In this case, one should speak of re-awareness of the human condition through apperception and 'noesis'; 33 we read in Voegelin:

Recapturing reality in opposition to its contemporary deformation requires a considerable amount of work. One has to reconstruct the fundamental categories of existence, experience, consciousness, and reality. One has at the same time to explore the technique and structure of the deformations that clutter up the daily routine; and one has to develop the concepts by which existential deformation and its symbolic expression can be categorized (Voegelin, 2006: 121).

What results from this? The result from this is a twofold practical-political consequence; its second part is what provides us the normative direction of critique and political agency. First, any politics that attempts to, or actually does, violate the human condition, i.e., that claims answers to existential intangibilities/ineffabilities and implements respective political strategies that promise any kind of ultimate resolution, are to be resisted and rebelled against; ${ }^{34}$ and second, humane politics, or politics that apperceives and is aware of the human condition, aims at allowing a diversity and plurality of expressions and symbolizations of the human condition, i.e., expressions and symbolizations of the search for answers to ultimate questions of political life without, however, providing answers to such questions. The thus concluding norm for directing critique and for political action is the creation of openness and of free spaces where such expressions and symbolizations can flourish. We can call these spaces ideal-typically democratic or republican spaces, or just spaces of 
humanity. We gain with Voegelin a language that does allow to regain (to 'recapture', as he says) normative thinking about humane politics without defining the contents of humanity. ${ }^{35} \mathrm{He}$ notes:

The core of political science is a noetic interpretation of man, society, and history that appears with the claim of critical knowledge of order vis-à-vis the order of that society in which, respectively, it emerges (Voegelin, 1990: 144).

Triangulating the notions of contingency/perspectivity of knowledge, of dialectic negation, and of 'noesis' leads to four propositions for a normative framework for humane and democratic politics. This will be discussed now.

\section{Four concluding propositions}

\section{The social, political, and cultural embeddedness of the researcher}

The notion of the time-space-contingency of knowledge and of the socio-political embeddedness of the researcher as discussed by Morgenthau is a fundamental notion of a hermeneutic understanding of social and political research. This notion implies the idea of situated knowledge. ${ }^{36}$ It seems indispensable for meaningful critique to be aware of its own standpoint from, and embeddedness out of which, critique is being exerted. This seems to be for two reasons: the relation to, and perspective on, the 'object' criticized seems only to be adequate and suitable for critique when and if both the 'criticizer' and the 'critiqued' are understood in their individual contexts. For example, maybe self-evident, but still worthwhile to emphasize, an analysis and critique of a specific foreign policy that does not take into account domestic social and political rationales and conditions behind that policy is not as valid, meaningful, and powerful as a critique and analysis that does. But further to this, critique should also reflect upon the standpoint of the criticiser. Thus, from the notion of time-space-contingency of knowledge follows the social, political, and cultural situatedness of the researcher and the 'object-under-study' and therefore the perspectivity of critique as one of its conditions. 


\section{A research's self-criticality and self-refutability}

The notion of dialectic negation leads, too, to a theoretical and practical proposition. This proposition holds that there is always another, a next viewpoint and thus no absolute certainty about, and finality of, one's own theoretical view and practice. Consequently, this proposition leads to the necessity of an inherent and permanent criticality towards own theories and practices. In its further consequence, it reasons an intrinsic awareness of the refutability of one's theoretical view and practice. This might be because of concrete historical alternatives to actual political and social developments or because of counter-arguments to theoretical suggestions; however, this proposition also includes the normative moment that the theoretician and the politician should always procure for and anticipate alternatives. This critical-theory demand resembles the practical consequences of the phenomenological notion of the 'project-in-draft'-character of every theory and action (according to Alfred Schütz) as well as the notions of 'différance' and erasure in Jacques Derrida: the opposite is inherent in and authentic to everything, thus identity as linear and coherent beingwith-oneself is an illusion; every being is transformative and bears within it its own contradiction. ${ }^{37}$

\section{Social sciences/humanities and the apperception of humanity}

While both previous propositions of embeddedness/situatedness/perspectivity and of self-criticality/ self-refutability are as conditions of critique "only" meaningful in a deconstructive function, the notions of apperception and 'noesis' deliver normative standards for rearticulating and reconstructing political knowledge and order. Saying this, does not belittle the importance and relevance of the former, however, points to the necessity of a rearticulating and reconstructive moment in theory and practice. Critique needs direction to be meaningful. This seems to be a further condition of critique for two reasons: first, to direct the critique itself because critique is not an end in itself, but serves some purpose. In short, critique is less meaningful if it were only about undoing a theoretical or practical position without pointing a way out after deconstruction. However, this requires explicit normativity; but how to frame and specify such normativity? Second, the critiqued is left in a better position when he/she is being suggested theoretical and/or 
practical alternatives and visions. Thus, the question also seems to be about the normativity for this reconstruction, bearing in mind that this normativity, as argued above, needs to be qualified against the previous notions of self-criticality/self-refutability and contingency/perspectivity. Only then is the triangulation (as mentioned in the beginning of this paper) as the structure of the argument presented here about conditions of critique fulfilled. Voegelin's notion of 'noesis' seems to provide the explicit normativity required for the triangulation of conditions of critique. It provides the language that is needed to cast the direction of reconstruction and re-articulation - which are virtually one and the same process since, as Derrida and Lyotard emphasize, every deconstruction is in itself the re-articulation of a new narrative that is genuinely normative. ${ }^{38}$ Therefore, the claim to deconstruct without normativity is nonsense.

The notion and language of 'noesis' tries to articulate humanity as the normative direction of critique. Without defining the content of humanity and humane politics - this would violate the two previous notions of self-criticality and self-refutability and contingency as well as the anthropology underlying the notion of 'noesis' itself - 'noesis' does stress the indispensable and major status of human experience, including its contradictions, ambiguities, "intangibilities", and "ineffables" before and paramount to all questions of institutional design, policy arrangements, and state sovereignty. This does not hold that these questions were unimportant, rather than that they need to follow and serve humane ends and experience. Put differently: political order in all its aspects needs to resonate with human experience - that is always historical, social, political, cultural, thus context-specific and situated - and ultimately serves society, not being an end in itself and developing a life independent of society, but for the purpose of ministering society. As was discussed and developed above, the resonance of political theory and political practice with humanity and human experience can and needs to be determined through deliberation that articulates and symbolizes its norms, desires, values etc. as well as through the creation and opening-up of fora for such deliberation and symbolization. Here, deliberation and symbolization do not follow any purpose apart from articulating itself, having been granted the function as 
yardstick for the resonance of political order that needs to be both open for and reflective upon such deliberation and apperceiving of human experience and its casting within contradictions, ambiguities, intangibilities, and ineffabilities. Non-apperception and non-resonance arises whenever deliberation and symbolization and their open fora for expression are shut down, hindered to articulate, and violated through epistemic or political ideologies, i.e., one-sided knowledge claims, unilateralism in international politics, military and direct violence etc. in the worst and most obvious cases; and prohibitions to ask questions, censorship, including self-censorship, stereotypes and prejudices, a-historical assumptions and their rationalizations, etc. etc., in short, all forms of cultural and structural violence ${ }^{39}$ in more subtle cases.

\section{The Non-Irreversibility of politics}

In terms of politics, the triangulation of 'noesis', contingency/perspectivity, and self-criticality/selfrefutability results in the important policy framework of the non-irreversibility of policies. The idea that policies must not cause irreversible consequences is also implicit in the early discussions of environmental justice and generational accountability. The triangulation of conditions of critique results in a similar argument, however, theoretically differently (and I would argue more deeply) founded. First publications emerged in German academic debates under the term "Umweltgerechtigkeit" in the 1980s in the context of the emergence of the Green Party, then as 'environmental justice' in US and subsequently in UK debates from the 2000 s to present-day. A fundamental difference to the argument developed here is, however, that whereas most debates on environmental justice $^{40}$ assume accountability of environmental degradation to arise after it happened, thus in relation to the settling and elimination of consequences, the argument here holds that policies that lead to irreversible consequences are to be avoided in the first place. Contingency, refutability, and noetic apperception of theory and practices triangulate two conditions of human knowledge and practice (contingency; refutability) with a normative claim (apperception). This catalogue of (conditions of) critique identifies policies as ignorant of conditions intrinsic to knowledge and practice always when and if policies are conducted which are of non-irreversible consequences. 
Such policies violate the principle of contingency and refutability and contradict the openness demanded by 'noesis', and are therefore to be seen as human hubris, rather than politics that resonates with human experience. ${ }^{41}$

Political examples to illustrate this point are many: from international security politics and to the nuclear condition, to environmental exploitation, to energy politics, to all politics that include questions of and decisions over life and death, including humanitarian intervention, immigration and asylum politics, urban development, conflict resolution, etc. etc. The drafting of policies that are informed by and include their own (partial) reversibility appears as a dictum for humane politics and society, not only in terms of generational accountability, but also in terms of intrinsic conditions of human knowledge and agency. The ability to turn back the wheel of consequences that have been triggered by implementing or simply allowing certain politics to happen, or to prevent policies with irreversibly harming and destructive consequences in the first place appears as the only accountable political agency in times of political means that have the potential to destroy once and for all all of humankind. Examples of such political means are many; what comes to mind instantly are the still massively existing and intact nuclear weapon arsenals and respective conflict scenarios, global warming and environmental degradation, and the exploitation of finite energy resources.

This links the arguments presented here to the aspect of crises and crises prevention. There might be typical crises phenomena as the result of Western modernity, as argued by Marcuse, Morgenthau, and Voegelin; however, the analysis of crises and the awareness of their causes is one thing, to reflect upon and possess eventually a practically applicable framework for agency-withincrises and for possibly preventing crises is another. While the former seems epistemologically inevitable, but practically insufficient, the later seems politically necessary. The dictum of avoiding policy irreversibilities appears as such a framework. Saying this, several main questions arise for further research: How to define, specify, and assess irreversiblities? Also, at which scale and scope of consequences to speak of their irreversibility? These are questions for further elaboration. 
To end with, and critical of, but inspired by Morgenthau: it is not enough to subscribe to an ethics of evil due to the impossibility of pure ethical behaviour ${ }^{42}$, but to possess a theoretical and practical framework for self-reflective, self-constraining, and moderate politics that attempts to procure the avoidance of evil in the first place. The triangulation of the three principles of contingency, self-refutability, and noetic apperception as conditions of critique appears as such an attempt. 


\section{Notes}

1 This question what critique consists of is widely discussed, without, however, reflecting upon the conditions of (their) critique; see, for example, writings of and on Derrida, Foucault, Butler, Fraser, or the Habermas-Foucault debate. See also foundational texts on critique in philosophy and social theory Horkheimer (1999 [1937]), Horkheimer/Adorno (2002), but also Heidegger, primarily Being and Time (1962), 'Identität und Differenz' (2006) and 'Zur Sache des Denkens' (2007).

$2 \quad$ See Marcuse (2002 [1964]) and (1968).

3 See Morgenthau (1944), (1960), (1959a), (1955), (1945a), (1945b), (1962a), (1962b), (2004).

4 See Voegelin particularly his Autobiographical Reflections (2006), "What is Political Reality?" (1990) and (1952).

5 It would of course be misleading to claim that Morgenthau, Marcuse, and Voegelin were the only scholars whose oeuvres would make the arguments of perspectivity of knowledge, negation, and noesis, however, they seem to communicate from their work most pronounced, even if not explicitly introduced by them as conditions of critique, but more as theoretical claims, and not always in a self-applied manner. Their oeuvres nevertheless promise to furnish important inspiration for the question at hand.

6 For this argument, see further discussions in Behr (2014).

7 See hereto The Primacy of Persons in Politics (2013).

8 See my preliminary outlines of the argument in 'Security Politics and Public Discourse: A Morgenthauian Approach’ (2013) and Behr and Roesch (2013).

$9 \quad$ See in his Politics Among Nations from the 1954-edition onwards.

10 See Hans J Morgenthau Archive, Law Library, Library of Congress Washington, Box 33.

11 From his Mediationes (1996); see also 'Descartes' Epistemology', Stanford Encyclopaedia of Philosophy; similar epistemological positions can be assigned to Spinoza and Leibniz (see 'Rationalism vs. Empiricism', ibid.).

12 See for this fundamental realist epistemological position Feldman (1999) who writes: 'The application of the general idea of context dependence to knowledge attributions is straightforward. What it takes for a knowledge (...) to be true can vary from context to context' (1999: 93); see also Feldman (2001) and DeRose (2009).

13 See Nietzsche (1980). Hereto, also interesting, is Emmanuel Lévinas's argument that the 'purely empirical is that which received signification, not that gives it' in his paper 'Meaning and Sense' (1996: 38).

14 Morgenthau used the metaphor of a 'map' frequently: see 1955, 1959a, 1959b, 1971.

15 See here also Turner/Mazur (2009: 492): 'The centrality of power and interest is not derived directly from the facts of international politics (...) Power and interest are made central by the standpoint around which we have chosen to organize our inquiries'. In their interesting and in many parts agreeable paper, Stephen Turner and George Mazur commit, however, the 
same error which they otherwise criticize: namely to single out one author as the influential figure for Morgenthau despite a lack of textual evidence in Morgenthau's writings themselves. In their case it is Max Weber. On the other hand, it is hard to understand why Turner and Mazur, while looking for these kind of influences on Morgenthau, neglect Karl Mannheim even though his influence is most obvious when Morgenthau adopts and endorses Mannheim's concept of Standortgebundenheit.

16 See hereto Morgenthau's early lectures on Aristotle in the 1947 winter term at the University of Chicago (especially that of 20th February) where he understands realism, rationalism, and empiricism (also idealism) as epistemologies while realism means for him primarily the social, political, and historical contextualization of theory and agency instead of the analysis of, and action in, reality due to abstract principles.

17 See in this regard: '(Science) has destroyed (...) our faith in the power of reason to discover the truth and to demonstrate its validity. The impasse in which we find ourselves today, philosophically speaking, is the result of this destructive attack of science upon philosophy the result of the demonstration by science that there is a truth beyond which science can discover and make plausible what philosophy cannot' (2004: 22).

18 With reference to his Scientific Man vs. Power Politics (1946) he notes that '(it) must suffice here [i.e. 1962a] to state dogmatically that the object of social sciences is man, not as a product of nature but as both the creature and creator of history in and through which his individuality and freedom of choice manifest themselves' (27). And from his Second of his 'Six Principles ...' we know him arguing: 'Political realism (...) requires (...) a sharp distinction between the desirable and the possible - between what is desirable everywhere and at all time and what is possible under the concrete circumstances of time and place.'

19 Most explicit here may be Schütz and his differentiation between two levels of social 'reality' and respective constructions (see Schütz, Collected Papers I, The Problem of Social Reality [1962]; also his The Phenomenology of the Social World [1972]).

20 See here especially Horkheimer (1999[1937]).

21 See One-dimensional Man, Introduction. One could here, of course, go back into the wider context of Marxist and neo-Marxist theory, however, for the purpose of elaborating the principle of dialectic negation for the argument intended here, it shall suffice in this paper to reflect upon writings in the context of the Frankfurt School.

22 See, of course, their Dialectic of Enlightenment.

23 Again, this notion of dialectic could and would need to be elaborated in its historical dimensions pursuing this idea in Hegel and Marx and their receptions, but as before, it's here about this notion for the purpose of the argument of this paper and not about an historiography of respective ideas.

$24 \quad$ Negations, 1968: 67.

25 This points to inner contradictions in Marcuse's theory that - again - shall not be discussed here as this paper is about the notions of dialectic and negation as they are important for argument made here about the conditions of critique for which these notions are important irrespective of individual contradictions in specific authors.

26 See for further discussion of both arguments below and endnote 37. 
27 As before with regard to Marcuse, this paper is not interested in tracing the philosophical history, comprising the reception of ideas, above by Marcuse and here by Voegelin, but wants to elaborate the basic idea of, here, 'noesis' for its utilization for the papers' own argument.

28 More on this below.

29 In this German writings Voegelin terms this 'Spannung zum Grund'; see Anamnesis, "Was ist politische Realitaet?", 1966; Engl. see Voegelin, "What is Political Reality?", Anamnesis (1978).

30 We read: 'The tension toward the ground is the material structure of consciousness but not an object of propositions; rather it is a process of consciousness having degrees of transparency for itself. In the noetic experience, consciousness attains its optimum luminosity in which the tension toward the ground can interpret its own logos'; "What is Political Reality?" (1978: 146).

31 See hereto the excellent analysis of Voegelin in (1999 [1938]).

32 Voegelin's concept of ideology evinces similarities to the understanding of Arendt and also Morgenthau; see Arendt (1953), (1958), (1969), (1970); Morgenthau amongst others (1944), (1946).

33 We likewise read in Voegelin: 'The noetic experience, interpreting itself, illuminates the logos of participation' (1978: 154).

34 Voegelin calls this turning away and withdrawal from humanity 'apostrophe' and a disease of mind; see Autobiographical Reflections (2006: 125-126).

35 This norm is surprisingly similar to Derrida's notion of 'aporetic experience of the impossible' (Derrida, 1993: 15), symbolized by 'ad-vent' and 'event' as what is yet to come, but impossible to grasp, as well as to his claim of the opening-up of spaces for these impossibilities to be and to (be)come; however, Vogelin is more political in his claim, however, whereas Derrida's notion is more epistemological (but likewise points the way to rearticulation after deconstruction). For a more detailed discussion of Derrida in this context, see Behr, 2014.

36 See amongst other, Cook (2005), Haraway (1988), Hoeber-Rudolph (2005).

37 Further discussion and literature references, see Behr, 2014.

38 For Derrida see the discussions and further literature in Behr, 2014; for Lyotard see his $L a$ condition postmoderne (1979).

39 See Galtung $(1969,1990)$ on structural and cultural violence.

40 See for example, Schlosberg (2007), Dobson (1999), Rhodes (2003).

41 With regard to the notion of hubris in relation to perspectivity and contingency of knowledge, see Behr and Roesch (2013).

42 See his 'The Evil of Politics and the Ethics of Evil' (1945b). 


\section{References}

Arendt H (1953) Ideology and Terror: A Novel Form of Government. Review of Politics 15 (3): 303-327.

Arendt H (1958) The Human Condition. Chicago: University of Chicago Press.

Arendt H (1969) Reflections on Violence. Reprinted in New York Review of Books, 27 February.

Arendt H (1970) On Violence. Orlando: Harcourt.

Behr H (2013a) Security Politics and Public Discourse: A Morgenthauian Approach. In: Bevir M, Daddow O, Hall I (eds) Interpreting Global Security. London: Routledge, pp. 160-176.

Behr H (2014) Politics of Difference. London and New York: Routledge.

Behr H and Rösch F (2013) Hans J. Morgenthau and the Ethics of Anti-Hubris. In: Troy J (ed.) Religion and the Realist Tradition. Routledge, pp. 11-128.

Cook I et al. (2005) Positionality/Situated Knowledge. In: Atkinson D, Jackson P, Sibley D, Washbourne N (eds.) Cultural Geography: A Critical Dictionary of Key Concepts. London: I.B. Tauris, pp. 16-26.

DeRose K (2009) The Case for Contextualism. Oxford: Oxford University Press.

Derrida J (1993) Aporias. Stanford: Stanford University Press.

Descartes R (1996 [1641]) Discours de la methode; and Mediations on first philosophy. Weissman D (ed.) New Haven: Yale University Press.

Dobson A (1999) Fairness and Futurity. Essays in Environmental Sustainability and Social Justice. Oxford: Oxford University Press.

Feldman R (1999) Contextualism and Skepticism. Nô̂s 33 (s13): 91-114.

Feldman R (2001) Skeptical Problems, Contextualist Solutions. Philosophical Studies 103 (61): 6185.

Galtung J (1969) Violence, Peace, and Peace Research. Journal of Peace Research 6 (3): 167-191.

Galtung J (1990) Cultural Violence. Journal of Peace Research 27 (3): 291-305.

Haraway D (1988) Situated Knowledges: The Science Question in Feminism and the Privilege of Partial Perspective. Feminist Studies 14 (3): 575-599.

Heidegger M (2006) Identität und Differenz. Gesamtausgabe, I. Abteilung: Veröffentlichte Schriften, Band 11, Frankfurt/M: Vittorio Klostermann.

Heidegger M (2007) Zur Sache des Denkens. Gesamtausgabe, I. Abteilung, Bd. 14.

Heidegger M (1962) Being and Time. Translated by John Macquarrie and Edward Robinson. New York: Harper Collins Publishers.

Hoeber-Rudolph S (2005) The Imperialism of Categories: Situating Knowledge in a Globalized World. Perspectives on Politics 3 (1): 5-14.

Horkheimer M (1999 [1937]) Traditional and critical theory. In: O'Connell M (ed.) Critical Theory: Selected Essays, New York: Continuum Press, pp. 188-243. 
Horkheimer M and Adorno TW (2002) Dialectic of Enlightenment. Stanford: Stanford University Press.

Lévinas E (1996) Basic Philosophical Writings. Peperzak AT, Critchley S, Bernasconi R (eds) Bloomington, IN: Indiana University Press.

Lyotard F (1979) La condition postmoderne. Rapport sur le savoir. Paris: Editions de Minuit.

Mannheim K (1936) Ideology and Utopia. London: Routledge.

Mannheim K (1984) Die Methoden der Wissenssoziologie. In: Lenk K (ed.) Ideologiekritik und Wissenssoziologie. Frankfurt: Campus, pp. 203-12.

Marcuse H (1968) Negations: Essays in Critical Theory. London: The Penguin Press.

Marcuse H (2002 [1964]) One-Dimensional Man. London: Routledge.

Morgenthau HJ (1944) The Limitations of Science and the Problem of Social Planning. Ethics 54 (3):174-185.

Morgenthau HJ (1945a) The Machiavellian Utopia. Ethics 55:145-147.

Morgenthau HJ (1945b) The evil of politics and the ethics of evil. Ethics 56(1):1-18.

Morgenthau HJ (1946) Scientific Man vs. Power Politics. Chicago: University of Chicago Press.

Morgenthau HJ (1947) Lectures on Aristotle in the 1947 winter term, University of Chicago (especially that of 20th February) (Hans J. Morgenthau Archive, Box 76). Washington, DC: Library of Congress.

Morgenthau HJ (1952) Lecture on "Philosophy of International Relations", University of Chicago (Hans J. Morgenthau Archive, Box 81). Washington, DC: Library of Congress.

Morgenthau HJ (1954) Politics Among Nations. The Struggle for Power and Peace. New York: Knopf.

Morgenthau HJ (1955) Reflections on the State of Political Science. The Review of Politics 17 (4):431-460.

Morgenthau HJ (1959a) The nature and limits of a theory of international relations. In: Fox W (ed.) Theoretical Aspects of International Relations. Notre Dame: Notre Dame University Press, pp. 15-28.

Morgenthau HJ (1959b) Education and World Politics. Daedalus No. 88: 121-38

Morgenthau HJ (1960) The social crisis in America: Hedonism of status quo. Chicago Review 14 (2): 69-88.

Morgenthau HJ (1962a) The Intellectual and Political Functions of a Theory of International Relations. In: Morgenthau HJ (ed.) Politics in the 20th Century, Vol. I, The Decline of Democratic Politics. Chicago, IL: University of Chicago Press, pp. 62-78.

Morgenthau HJ (1962b) The Commitments of a Theory of International Politics. In: Morgenthau HJ (ed.) Politics in the 20th Century, Vol. I, The Decline of Democratic Politics. Chicago, IL: University of Chicago Press, pp.55-61.

Morgenthau HJ (1971) Power as a Political Concept. In Young R (ed.) Approaches to the Study of Politics. Evanston: Northwestern University Press, pp. 66-77.

Morgenthau HJ (2004) Political Theory and International Relations, 'Hans J. Morgenthau on Aristotle's The Politics'. Lang, AF (ed.). Westport, Connecticut: Praeger.

Nietzsche F (1980) On the Advantages and Disadvantages of History for Life. Translated by Peter Preuss. Indianapolis, IN: Hackett Publishing Company, Inc. 
Rhodes EL (2003) Environmental Justice in America. Bloomington, IN: Indiana University Press.

Schlosberg D (2007) Defining Environmental Justice: Theories, Movements, and Nature. Oxford: Oxford University Press.

Schütz A (1962) The Problem of Social Reality, Collected Papers I. The Hague: Martinus Nijhoff.

Schütz A (1972) The Phenomenology of the Social World. Translated by George Walsh and Frederick Lehnert, with an Introduction by George Walsh. London: Heinemann (originally in German as Der sinnhafte Aufbau der sozialen Welt, 1932).

Turner S and Mazur G (2009) Morgenthau as Weberian Methodologist. European Journal of International Relations 15 (3): 477 - 504

Voegelin E (1952) The New Science of Politics. Chicago: University of Chicago Press.

Voegelin E (1990) What is Political Reality? in Anamnesis, translated and edited by Gerhart Niemeyer. Columbia/London: University of Missouri Press, pp. $141-213$.

Voegelin E (1999 [1938]) Die politischen Religionen [The political religions]. The Collected Works of Eric Voegelin, Volume 5. University of Missouri Press.

Voegelin E (2006) Autobiographical Reflections. The Collected Works of Eric Voegelin, Vol. 34. Edited and with Introduction by Ellis Sandoz. Columbia and London: University of Missouri Press.

von Heyking J and Heilke T (eds.) (2013) The Primacy of Persons in Politics. Washington, D.C.: The Catholic University of America Press. 